\title{
Overview of Italian Government's Stance on Albania's Withdrawal from Warsaw Treaty de Facto in 1961 and de Jure in 1968
}

\section{Etleva Smaçi}

Lecturer at Armed Forces Academy of Albania

\author{
Doi:10.5901/mjss.2017.v8n2p155
}

\section{Abstract}

This article tries to analyze Italian government's stance after Albania's de facto withdrawal from the Warsaw Treaty in 1961 and de jure denunciation of this treaty in 1968. The retreat of Soviet troops from Vlora Naval Base had a considerable impact on Italy's foreign relations with Albania in many regards. Concerning internal interests, Italy had a close relationship with Albania and had always demonstrated the willingness to enhance her influence in this respect. On the other hand, for Italy being a NATO member country, Albania's withdrawal from the Warsaw Treaty was an enormous relief. The possibility that the two superpowers clash on the Adriatic Sea was considerably minimized. This led to a genuine interest in Albania. Albanian political immigrants in Italy played a major role in enhancing this attention. Nevertheless, because of the communist regime in Albania, the rapprochement wanted by Italy remained merely a desire which did not exceed bilateral economic relations. Viewed as an opportunity for Albania to open up to the West, this effort constitutes another chance deliberately "missed" by the regime at home.

Keywords: Italy, Albania, Otranto, Warsaw Treaty, NATO

\section{Introduction}

Albania became a member of the Warsaw Treaty on 14 May 1955. This was the first important treaty for Albania, which had little influence on the international arena. The inclusion of Albania in this Treaty - despite designation, it was a political and military pact - occurred primarily due to her favorable geostrategic position on the Adriatic Sea, and not so much for the fact of being a communist country. Of the eight signatories, Albania and East Germany had no previous treaties with the Soviet Union. Albania had a treaty of friendship and reciprocal assistance with Bulgaria.

The major reason for preventing Albania from signing a treaty had its roots in the Yalta conference. During the first years, Stalin had deliberately left Albania under the Yugoslav umbrella. Yugoslavia was treated as a country being outside of blocs, and each movement to include Albania in the socialist camp caused an escalation of conflict between the Soviet Union and the allies of the North Atlantic Treaty Organization (Lauka.I \& Ymeri.E, 2006)

But the panorama for Albania changed when she turned into a hotspot of the Cold War on the Adriatic Sea almost 2 years after she joined the Warsaw Treaty. One of the most envied spots of the coast, Vlora Bay, would become a military base of the Warsaw Treaty in 1957, based on the bilateral agreement between the Soviet Union and Albania. The arrival of the Soviet crews and their installation at Vlora Base constituted a real stationing of troops in the territory of Albania. Although Albania was a member country of the Warsaw Treaty, the arrival of these crews cast shadows of doubt. While in some countries, such as Romania, the Soviet Union was preparing the withdrawal of troops, the opposite was the case in Albania.

The Russian threat was short-lived. Albania not only was not equipped with missiles but saw herself outside of the Warsaw Treaty, while being considered the "prodigal son" because of the conflict with the Soviet Union and alliance with China. If Albania's membership in the Warsaw Treaty had aroused neighbors' dissatisfaction and fear, her exit was some relieving news, as this would avert an armed conflict.

The Adriatic Sea and Otranto Channel became the nearest spot of military and naval confrontation between the 
two blocs - NATO and Warsaw Treaty. (Bashkurti. L. 2003). This unexpected turn of Soviet-Albanian relations was covered in the Italian press, as well. Telegrams sent from the Albanian representative body in Rome to the Ministry of Foreign Affairs notified that one of the most important newspapers of the country, "Corriere della Serra" published on 23 December, a month after the meeting at Moscow, the news that the Soviet Union had stopped providing Albania with wheat."

The Italian government considered Albania's withdrawal from the Warsaw Treaty as an opportunity for her to turn to the West. Italy was aware that the communist regime led by Hoxha was a Stalinist regime and that the dictator himself was a fierce follower of Stalinist school. But Italy was interested in extending her influence over Albania, despite the possibility that Enver Hoxha might continue to be in power. However, two moments are worth highlighting: Albania's de facto withdrawal in 1961 and the denunciation of the treaty in 1968.

\section{Aim}

The aim of this article is to analyze the perspectives and stances of two governments: Italian and Albanian ones during 1961-1968. This new relationship was initiated following Albania's withdrawal from the Warsaw Treaty.

\section{Hypothesis}

The article tries to argue that the Italian government was considerably interested in improving relations with Albania, after the latter retreated from the Warsaw Treaty.

\section{Methodology}

The main methods used in this article are analytic and comparative. Based on research into two major archives - the Archives of the Ministry of Foreign Affairs, and Central State Archives of People's Socialist Republic of Albania - the article sheds light on facts, conversations, telegrams exchanged among Albanian representatives in Rome and Italian representatives. In addition, data have been amassed from the Italian press. These have been compared with several domestic and foreign writings on Albania, and the Treaty of Warsaw.

\section{Italian Government's Reaction After Albania's de Facto Withdrawal from the Warsaw Treaty (1960-1964)}

In order to better understand how this break was perceived and what expectations the Italian government had of it, we have compared two sources. The Albanian sources of the Ministry of Foreign Affairs and external sources, where records of the US Department of State for Albania are specifically included. Firstly, let us focus on the Albanian sources from the Ministry of Foreign Affairs. Shortly before severing the relations with the Soviet Union - the rift between the two countries was obvious - the prime minister of the country Mehmet Shehu would declare at the People's Assembly, on 25 October 1960, that:"relations with Italy were normal, and had improved", expressing also the desire that the Italian party do the same thing.

This declaration did not go unnoticed by the Italian party who followed carefully all the developments in Albania. Based on the reports of Albania's Legation in Italy there were observed some serious steps of political nature for a rapprochement with Albania - always hoping for a change in the course of Albanian policy.) It appears that an indication of rapprochement was the near-double increase of commercial volume with Italy. Being totally isolated, Albania needed more than communist China's aid. Thus, the change of political course was regarded as being conditioned by circumstances, and Italy had her own expectations.

These expectations were supported by Italian representative Ludovico Monti at the meeting of the European Commission held in Venice, in April 1962. Analyzing Albania's situation and the steps to be undertaken by her, he had promoted the idea of supporting Albania economically, even though she did not adhere to this organization. The year 1963 witnessed a considerable increase of this interest. Information coming from the Albanian Legation show that Italy was trying to improve bilateral relations. But the response to Italy's involvement was that" under the leadership of the Party, Albania wanted to improve relations with Italy by enhancing trade and cultural exchanges."

On 2 April 1963, Behar Shtylla would hold a report about international relations of People's Socialist Republic of Albania for year 1962 in front of the workers of the ministry he was leading. Analyzing relations with other countries excluding the states of the socialist camp- Shtylla expresses the conviction that capitalist powers "had cherished illusions that Albania would withdraw from the socialist camp and, in one way or another, would approach the West." Of the 
powers directly interested, he mentioned France and Italy, who, according to him, were pursuing the "open door" policy for rapprochement. But along with indirect offers, he states that there were also threats.

Shtylla's report was considerably based on the information received by the Albanian Legation in Rome. The head of the Legation, Pani, analyzing the meeting of 10 March 1963 with the Italian representative in Tirana, Gabrici, expressed the conviction that the Italian government followed attentively the stance and policies pursued by the Albanian party. Furthermore, according to Pani, they were hoping for possible changes. But in Pani's observations it was evident that he did not approve of the policy pursued by the Albanian government, which he defines as "a revolutionary and consequent attitude." In fact, despite this disapproval, Italy's main aim was not to overthrow the regime of Enver Hoxha, which could consequently bring to power a pro-Yugoslav or pro-Soviet regime. This could return Albania to the Warsaw Treaty.

In his analysis, Pani also mentions the very essence of this interest - the stance of Albania as seen by Italy being a NATO member country, and having major influence on region. He sheds light on conversations held in Italian political and military circles, where a careful attitude toward Albania was requested. In these conversations Albanian-Soviet developments were considered really important for Italy.

Enver Hoxha was aware that the "open door" policy was not approving of his form of regime, but also did not pose an eminent threat, like in Yugoslavia's case. That is why he considered Italy only as a suitable trading partner. Italy herself had obstacles toward this rapprochement. One of the most conspicuous ones was linked to the fact that the Russian communism was replaced by the Chinese communism. Pani reported that for Italians the progress of Albanian Chinese relations was an important factor for subsequent steps. But this interest shown by ltaly was not viewed favorably by Greece who did not want Italy to return to the Balkans. It should be stressed that the attitudes of Italy and Greece, as two NATO member countries, abode by the decisions and interests of this organization, but their national interest in Albania was different. Some scholars have arrived to the conclusion that "Italy wanted to extend her international influence, but at the same time respected the sovereignty of Albania." ( Griffith, W.1963 p.169) That is why Enver Hoxha considered "Italy as a less risky country." (Kaba,H, 2010, p.179)

The Italian interest after Albania's de facto withdrawal from the Warsaw Treaty proves this. During 1961- 1962, when there spread the news of a possible attack against Albania by Yugoslavs, with the support of Russians, one of the main providers of information on Albania for the US Department of State were Italian sources. Besides that, it attracted the American attention to the risk that a potential joint Russian and Yugoslav plan against Albania would pose. The concern of Italian representatives was evident in other countries, as well. The Italian secretary in London discussed the hypothesis of a possible attack on the Foreign Office.

At the end of 1963, which also marks the conclusion of the first phase of Albania's being outside of the Warsaw Treaty, it can be said that Italian perception of Albania was that of a spokesperson of Beijing. As a consequence, relations between the two countries remained at an economic level. The highest achievement of this period was the transition from Legation to embassy. Fear of Albania's return to the Warsaw Treaty and socialist camp was still present, since the latter continued to legally be a member of NATO's rival treaty.

\section{Italian Attitude After People's Socialist Republic of Albania Denouncing the Warsaw Treaty}

Albania remained a formal member of the Warsaw Treaty even after 1965, when the last invitation was extended to her. Even the summer of 1968 found her like this. The events happening in the communist bloc did not go unnoticed in Tirana. Czechoslovakia was invaded by the troops of the Warsaw Treaty nearly a month after. In Czechoslovakia there occurred what the communist regime feared would happen in Albania, too - an aggression in the name of the Warsaw Treaty. Absence of a major reason for a long time was also one of the factors that conditioned her formal stay in the Warsaw Treaty. The case of Czechoslovakia was the right moment to take the big step, legally withdrawing, and denouncing the treaty. The international opinions were vehement.

Nearly two weeks following the invasion, the communist leaders concluded that the situation was ideal to sever ties that were no longer functional, but which could be used to harm Albania. No later than two days came a public pronunciation in the newspaper "Zëri i Popullit" through the joint declaration of the Central Committee and Ministerial Council of the People's Republic of Albania [PRA], considering the Warsaw Treaty as an instrument being exploited by "the revisionist clique of Soviet Union". For the communist leaders of Albania, this treaty was brutally harmful to the interests of the Albanian population. The same argument was employed both for signing it to protect the interests of the country, and castigating it: "To defend the motherland and socialism, PRA must denounce the Warsaw Treaty and be liberated from obligations deriving from this treaty."

The assembly of 5 September 1968 (Plenum V of the Central Committee of People's Republic of Albania) was 
opened by Enver Hoxha. He declared in front of the plenum that the decision to denounce the Warsaw Treaty was taken, as this moment was favorable "having by our side all the rights, and political, ideological and lawful reasons. The role of propaganda could not be avoided by this decision, from which the PRA was thinking of having its own benefits. The enhancement of prestige was one of the profits mentioned by Enver Hoxha. But the biggest profit was in fact the deterrence of a potential danger, similar to Czechoslovakia. On September 11, a short press release of the fifth plenum of the Central Committee was published, where the subject of the plenum was mentioned but not its decisions. They would be made public two days later upon meeting of the Popular Assembly.

The session of the PA was held by the plenum's decision since "The Warsaw Treaty was no longer a peace Treaty but had become an enslaving Treaty." Mehmet Shehu requested that the Popular Assembly follow all juridical steps to condemn the treaty since "Being part of the Warsaw Treaty and calling yourself a member of it meant being part of an aggressive organization. This was the declaration of a man who 13 years ago had declared that "our membership in Warsaw Treaty has made the international position of the People's Republic of Albania solid and stronger than ever."

This was the last legal relationship of Albania with the Warsaw Treaty. The news of Albania's withdrawal from the Treaty was welcomed by the neighbors. The Yugoslavian advisor in Bulgaria stated that "the radio and press had transmitted positive news about this withdrawal." In a conversation with the Albanian representative, he implied that this action of the Albanian government was expected well by them. Also, the Italian government was pleased by this news. For her, Russian threat was now smaller for Albania and this fact calmed the Italian government, since Russians had no longer a gateway into the Adriatic sea and especially Sazan.

The Soviet aggression against Czechoslovakia made the Italian government reflect about her relationship with Albania, in adopting also a similar stance against this aggression. Italian ambassador Behman, during his meeting with the deputy Minister of Foreign Affairs Malile, appreciated Albanian's proper attitude concerning foreign policy. He also did not forget to mention his admiration for Albania's courage to leave the Warsaw Treaty in defense of their country. At the end of this meeting, Malile was extended an invitation from the Italian Minister Medici to Minister of Foreign Affairs Nesti Nase.

But the Albanian government with her representative Malile once again demonstrated the determination not to align with the West, even if this meant total isolation. Since the de facto withdrawal of 1961, Enver Hoxha had warned that there would be no change of principles of the party. To him, acceptable and indeed preferable were only trading relations. Albania's withdrawal from the Warsaw Treaty would have no impact on relations with Italy. Political immigrants in Italy had also hoped of this new movement of the communist regime. A telegram provides information about what this group thought. Referring to Asaf Libohova, Albania's withdrawal from the Warsaw Treaty was welcomed by Italians for many reasons.

The Albanian government being outside the treaty would permit the Italian government to be politically more active without having obstacles from her NATO allies, since now Albania was not engaged. Thus, it was predicted that in a near future Italy would develop political and economic relations with Albania. Italy's main purpose was to prevent the Russian fleet from having access to the Mediterranean, which was previously permitted by Yugoslavia. Italy insisted that the English fleet should have a gateway to the Mediterranean to handle the Soviets. Italy was so interested in this achievement of Albania that she was also willing to undertake military engagements. "We will not remain indifferent if Albania is attacked." For them, another invasion of Sazan by Russians was unacceptable.

The telegrams of the representatives of Ministry of Foreign Affairs of PRA in different countries cast light on Italian government's attitude about a possible attack of Albania from Russia. Along with a report from the representative body in Egypt, where the Italian ambassador had stated that "the presence of a Russian fleet on the Mediterranean was a big threat" there are other telegrams showing that Italy exploited Albania's de jure withdrawal from the Treaty to cause commotion and disguise some of her own problems. In a telegram from the Albanian ambassador in Rome on 07 October 1968 there is stated that the amplification of the commotion about a potential of Russian attack against Albania was used to cover some of the military expenses in the name of a Russian aggression on the Mediterranean.

The Italian press was sensitive to this topic, as well. The newspaper "Lo Spechio", on 13 October 1968 , almost a month and a half following the aggression on Czechoslovakia, analyzed that Albania's resistance to the pressure of the Soviet Union, antagonism of the neighbors, and isolation was a miracle. But the article also showed the other side of the coin, the declaration of the communist leader of Albania that if Albania was at risk, she would not be alone but would have Great China by her side. Of course, this writing did not intend to support the communist regime of Hoxha, let alone approve of the Chinese support. Thus, the idea emphasized was that neighboring Italy could provide more aid to Albania in such a situation than farway China.

The stance on the closeness with China was severe, since just as the Soviet Union, China also meant a risk to Italy with her communist influence on Albania. Another writing about this problem is mentioned in the telegram of 
Libohova. According to this telegram, the Italian admiral Fadin would prepare an article where he would highlight the importance of Albania's withdrawal from the Warsaw Treaty, which was deemed by Italians obligatory but courageous.

\section{Conclusion}

All the above-mentioned efforts made by the Italian government were considered a "hypocritical" behavior. For the Albanian government, it was clear that the Italian involvement was related to their fear of growing Russian expansion onto the Mediterranean. Also, to Albania, it was clear that Italy's rapprochement through economic and cultural exchanges aimed to have a primary role, in case Albanian government changed her political attitude. So, the directives were clear. Only economic relations, avoiding delegation exchanges. Furthermore, the secret service was charged with discovering plans of Italy and NATO for the Balkans, as well as receive information about the Russian fleet's plans for the Mediterranean. To the Albanian government, the reaction of Italy after the invasion of Czechoslovakia constituted merely a mechanism for Italy to profit from Albania.

The Albanian government viewed Rome's movements as demagogic, since she was part of NATO, along with the USA, both treating the aggression on Czechoslovakia as an internal issue of the communist camp. Such movements were regarded as being against the interests of the communist Albanian government, since it denigrated the socialist camp. The declarations by the Italian government of supporting Albania and appreciating her for withdrawing from the Warsaw Treaty were seen by the Albanian government with suspicion. They produced no visible effect in 1968 or afterward. The reason was clear. For the Albanian government, Italy aimed to decrease the revolutionary vigilance; however, she was considered a harmless country. Neither in 1961 nor 1968 did Albania open. Even after the denunciation of the Warsaw Treaty, which rightfully, like membership in it, can be considered one of the most crucial moments during the Cold War, everything remained "all quiet on the west front." This being an appropriate borrowing from the novel of E.M. Remarque, a representative of the writers of the lost generation. Albania lost herself at her own free will in "Hoxha" desert of self-isolating communism.

\section{References}

AMPJ, [Archives of the Ministry of Foreign Affairs], year.1960, file.466, p.10-11, Different information on relations with Italy; AMPJ year.1961, file.21, p..64, Analysis of mission's work in Rome;

AMPJ, year.1962, file.652, p.70, Reports of the directory ... the relations between two countries;

AMPJ, year.1963, file.797, p 10-11. Conversation between Albanian representative Pani and general secretary of Ministry of Foreign Affairs of Italy Catani;

AMPJ, year.1965, file.506, p.2-4, Information of the mission from the press about Albania;

AMPJ, year.1964, file.649, p.1-2,About the transformation of the Legation into an embassy ;

AMPJ, year 1968, file B/ VI -3, p.224

AMPJ, year.1968, file. 299, p.10-13,

AQSH, [Central State Archives ],Fund14 AP/OU, year.1968, file.1, p.7, Report of first secretary of PRA, Enver Hoxha;

Minister of Foreign Affairs of Albania, Reiz Malile, and Italian ambassador Noberto Behman;

AMPJ, year.1968, file. B/VI-3, TV, p.245;

AMPJ, year.1968, file. 303, p.27, Report about relations with Italy;

AMPJ, year.1968, file. 303, p.1-5, What the Italian press writes against our country;

AMPJ, year.1968, file. 3013, p.1-5, Report about relations with Italy;

AMPJ, yea.1969, file. 393, p. 55-65 Important issues on relations between Albania and Italy.

Bashkurti, L.(2003). "Diplomacia shqiptare në fillimet e luftës së Ftohtë”, Geer.

Kaba, H. (2010). Studime Historike, No.1-2

Griffith,.W. E. (1963) "Albania and the Sino - Soviet Rift", M.I.T Press.

NARA, File 767, A -1049, Julian P. Former - American First Secretary in Rome to D.C;

Journal Zëri Popullit, 27 may 1959

Journal Zëri i Popullit, 23 August 1968

Journal Zëri i Popullit, 13 September 1968

Journal Zëri i Popullit, 23 May 1955 